\title{
Development and Validation of a New Stability Indicating Ultra-Fast Liquid Chromatographic (RP-UFLC) Method for the Quantification of Luliconazole
}

\section{Paladugu Venkata Naveen* and Seru Ganapaty}

Department of Pharmaceutical Analysis and Quality Assurance, Gandhi Institute of Technology and Management (Deemed to be University), GITAM Institute of

Pharmacy, Visakhapatnam, Andhra Pradesh, India

*Corresponding Author: Paladugu Venkata Naveen, Department of Pharmaceutical Analysis and Quality Assurance, Gandhi Institute of Technology and Management (Deemed to be University), GITAM Institute of Pharmacy, Visakhapatnam, Andhra Pradesh, India.
Received: August 18, 2021

Published: September 06, 2021

(C) All rights are reserved by Paladugu

Venkata Naveen and Seru Ganapaty.

\begin{abstract}
Luliconazole is an antifungal agent. A new stability indicating RP-UFLC method has been developed for the estimation of Luliconazole using Shimadzu UFLC system (PDA detector) with Zorbox C8 column (150 mm $\times 4.60 \mathrm{~mm}$ i.d. $5 \mu \mathrm{m}$ particle size) in bulk and pharmaceutical dosage form and validated as per ICH guidelines. A mixture of tetra butyl ammonium hydrogen sulphate and acetonitrile was used for the chromatographic separation with a flow rate of $1 \mathrm{~mL} / \mathrm{min}$. and UV detection at $220 \mathrm{~nm}$. Linearity was observed over the concentration range of $0.1-100 \mu \mathrm{g} / \mathrm{mL}$ with linear regression equation $\mathrm{y}=89055 \mathrm{x}-1545.2\left(\mathrm{R}^{2}=0.9998\right)$. Forced degradation studies were performed and Luliconazole was found to be more sensitive towards acidic and oxidation conditions. The LOD and LOQ were found to be 0.0311 and 0.0981 . The method was validated and found to be precise, accurate and robust.
\end{abstract}

Keywords: Luliconazole; Forced Degradation Studies; Validation; ICH Guidelines

\section{Introduction}

Luliconazole (Figure 1) is an imidazole derivative and chemically named as (2E)-2-[(4R)-4-(2, 4-dichlorophenyl)-1, 3-dithiolan-2-ylidene]-2-imidazol-1-ylacetonitrile $\left(\mathrm{C}_{14} \mathrm{H}_{9} \mathrm{Cl}_{2} \mathrm{~N}_{3} \mathrm{~S}_{2}\right)$ with molecular weight 354.28. It is used as an antifungal agent [1]. The R-enantiomer of Luliconazole has only one chiral centre and the double bond which is adjacent to dithiolane moiety is in E configuration [2].

Different analytical methods such as spectrophotometry [3-5], TLC [6], HPTLC [6,7], RP-HPLC [8,9], RP-UFLC [10] and other liquid chromatographic methods involving the estimation of related [11] substances and experimental design [12] were published for the assay of Luliconazole in pharmaceutical formulations and biological fluids. In the present study we have developed a simple, accu- rate and economic stability indicating method for the quantification of Luliconazole in bulk and pharmaceutical dosage form. The method was validated as per ICH guidelines [13].

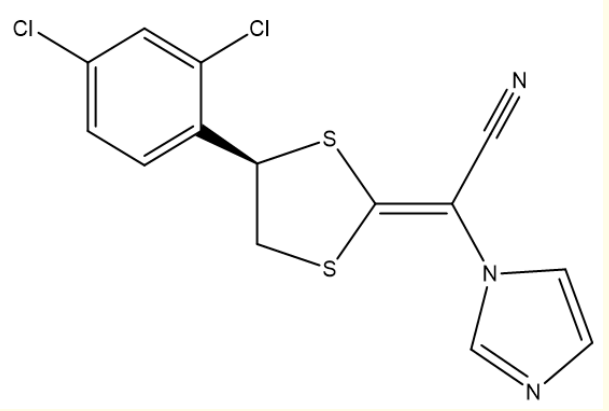

Figure 1: Chemical structure of Luliconazole. 


\section{Chromatographic conditions}

Shimadzu Model CBM-20A/20 Alite UFLC system (Shimadzu Co., Kyoto, Japan) equipped with photodiode array detector and Zorbox C8 column ( $250 \mathrm{~mm} \times 4.60 \mathrm{~mm}$ i.d. $5 \mu \mathrm{m}$ particle size) were employed for the chromatographic study. Mobile phase consisting of tetra butyl ammonium hydrogen sulphate and acetonitrile $(32: 68 \mathrm{v} / \mathrm{v})$ was used with a flow rate of $1.0 \mathrm{~mL} / \mathrm{min}$ were used as the optimised conditions and the eluted compounds were monitored at $220 \mathrm{~nm}$. Tetra butyl ammonium hydrogen sulphate is an ion pairing agent. The run time was 10 minutes and the sample injection volume was $20 \mu \mathrm{l}$.

Preparation of $10 \mathrm{mM}$ tetra butyl ammonium hydrogen sulphate solution:

3.395grams of tetra butyl ammonium hydrogen sulphate was accurately weighed and transferred in to a $1000 \mathrm{~mL}$ volumetric flask and made up to volume with HPLC grade water and used after filtration through the membrane filter.

\section{Preparation of stock solution of Luliconazole}

$25 \mathrm{mg}$ of Luliconazole was accurately weighed and transferred in to a $25 \mathrm{~mL}$ volumetric flask and dissolved in HPLC grade acetonitrile. The volume was made up to the mark with HPLC grade acetonitrile $(1000 \mu \mathrm{g} / \mathrm{mL})$ and dilutions were made with mobile phase and all the solutions were filtered through $0.45 \mu \mathrm{m}$ membrane filter prior to injection.

\section{Method validation [13]}

\section{Linearity}

A series of 0.1-100 $\mu \mathrm{g} / \mathrm{mL}$ Luliconazole solutions were prepared on dilution from the stock solution with mobile phase and each of the solution was injected into the UFLC system $(n=3)$ and the chromatogram was recorded. The peak area observed at the retention was noted and further mean peak area was calculated. Calibration curve was drawn by plotting concentration of Luliconazole solutions on the $\mathrm{x}$-axis and the corresponding mean peak area obtained on the y-axis.

LOD and LOQ were calculated from the standard deviation of response and also the slope of the corresponding calibration curve. LOD was calculated as 3.3 times the signal to noise ratio and LOQ is 10 times the signal to noise ratio.

\section{Precision}

Precision was evaluated intra-day and inter-day precision studies. Three different concentration solutions $(10,20,40 \mu \mathrm{g} / \mathrm{mL})$ of Luliconazole were prepared within the linearity range on the same day (intra-day precision) and on three consecutive days (inter-day precision) and the chromatographic study was performed. The mean peak area $(n=3)$ and thereby the \% RSD was calculated.

\section{Accuracy}

Accuracy was measured by spiking the drug formulation solution $(50,100,150 \%)$ with a known concentration of standard drug $(n=3)$. These studies were carried out and finally the \% RSD was calculated from the values obtained followed by the percentage recovery from the linear regression equation.

\section{Robustness}

The robustness of the method was proved by incorporating a very small changes in the optimized chromatographic conditions such as mobile phase composition $( \pm 2 \% ; 30: 70 \mathrm{v} / \mathrm{v}$ and $34: 66$ $\mathrm{v} / \mathrm{v})$, detection wavelength ( $\pm 2 \mathrm{~nm} ; 222$ and $218 \mathrm{~nm}$ ) and flow rate ( $\pm 0.1 \mathrm{~mL} ; 1.1$ and $0.9 \mathrm{~mL} / \mathrm{min}$ ).

\section{Forced degradation studies}

Forced degradation studies [14] were performed to determine the stability of Luliconazole towards stress conditions such as acidic hydrolysis, basic hydrolysis, oxidation and thermal degradation. The specificity of the method can be known from the stability studies and therefore Luliconazole was exposed to the following stress conditions and the stability was studied.

Acidic degradation was performed by heating Luliconazole solution with $1 \mathrm{~mL}$ of $0.1 \mathrm{~N} \mathrm{HCl}$ solution at $80^{\circ}$ for one hour on a water bath. The stressed sample was then cooled, neutralized with $1.0 \mathrm{~mL} 0.1 \mathrm{~N}$ sodium hydroxide solution, diluted with mobile phase and then $20 \mu \mathrm{l}$ of the solution was injected in to the UFLC system.

Alkaline degradation was performed by heating Luliconazole solution with $1.0 \mathrm{~mL} 0.1 \mathrm{~N}$ sodium hydroxide solution at $80^{\circ}$ for one hour on a water bath. The stressed sample was then cooled, neutralized with $1.0 \mathrm{~mL}$ of $0.1 \mathrm{~N} \mathrm{HCl}$ solution, diluted with mobile phase and then $20 \mu \mathrm{l}$ of the resulting solution was injected in to the UFLC system. 
Development and Validation of a New Stability Indicating Ultra-Fast Liquid Chromatographic (RP-UFLC) Method for the Quantification of Luliconazole

Thermal degradation was performed by heating the Luliconazole solution at $80^{\circ} \mathrm{C}$ for one hour on a water bath and then cooled, diluted with mobile phase and $20 \mu \mathrm{l}$ of the resulting solution was injected in to the UFLC system.

Oxidative degradation was performed by heating Luliconazole solution with $1.0 \mathrm{~mL} 30 \%$ hydrogen peroxide solution at $80^{\circ} \mathrm{C}$ for one hour on a water bath. The stressed sample was then cooled, diluted with mobile phase and then $20 \mu \mathrm{l}$ of the resulting solution was injected in to the UFLC system.

\section{Assay of Luliconazole in its topical dosage form (Cream)}

Luliconazole is available as a topical dosage form i.e. as Cream with brand names LULICON (Glenmark Pharmaceuticals), LULINAZ (Generic) (Labelled claim: $1 \% \mathrm{w} / \mathrm{w}$ ) and also as lotion, soap and cream with brand name as LULIFORD (Leeford Healthcare Ltd) (India).

$25 \mathrm{mg}$ of Luliconazole cream accurately weighed from two different brands in to two different beakers and heated on a water bath with continuous stirring till it melts and then the contents were quantitatively transferred in to two different $25 \mathrm{ml}$ volumetric flasks and acetonitrile was added. The resulting mixture was sonicated, filtered and then diluted with the mobile phase. $20 \mu \mathrm{L}$ of each of these solutions were injected in to the system and the peak area was noted from the resultant chromatogram $(n=3)$.

\section{Results and Discussion}

A new stability indicating RP-UFLC method has been developed for the estimation of Luliconazole in creams. The previously published methods for the assay of Luliconazole were briefly summarised and compared with the present proposed method in table 1.

\section{Method optimisation}

Initially a $10 \mu \mathrm{g} / \mathrm{mL}$ of Luliconazole was injected in to the UFLC system with the mobile composition 20: 80 and flow rate $0.8 \mathrm{ml} /$ min and a chromatogram was eluted where the system suitability parameters were not satisfied. During the optimization process the mobile phase composition, flow rate were varied (Table 2) and finally the previous Phenomenex column was replaced with a Zorbox column there by Luliconazole was eluted at 2.211 minutes where the mobile composition was 32: 68 and flow rate was 1.0 $\mathrm{ml} / \mathrm{min}$ (Trial 5). The chromatograms obtained during the optimisation process (Trials) were shown in figure 2.

\begin{tabular}{|c|c|c|c|}
\hline $\begin{array}{l}\text { Mobile phase }(\mathrm{v} / \mathrm{v}) / \\
\text { Detection wavelength }(\mathrm{nm})\end{array}$ & Linearity $(\mu \mathrm{g} / \mathrm{mL})$ & Remarks & Ref \\
\hline Methanol/296 & $5-25$ & Spectrophotometry (AUC) & [3] \\
\hline $\begin{array}{l}0.1 \mathrm{~N} \mathrm{HCl} \\
\text { Phosphate buffer }(\mathrm{pH} 2.0) / 294\end{array}$ & $\begin{array}{l}2-30 \\
10-30\end{array}$ & Spectrophotometry & {$[4]$} \\
\hline Methanol/295 & $3-18$ & Spectrophotometry (AUC) & {$[5]$} \\
\hline $\begin{array}{l}\text { Toluene: Isopropanol: Ammonia } \\
(90: 10: 0.5) / 297\end{array}$ & $\begin{array}{l}1-24 \mu \mathrm{g} / \text { band } \\
0.8-6 \mu \mathrm{g} / \text { band }\end{array}$ & $\begin{array}{c}\text { TLC } \\
\text { and HPTLC }\end{array}$ & [6] \\
\hline Toluene: Methanol: Ethyl Acetate (6:2.5:0.5) & $0.1-0.6 \mu \mathrm{g} / \mathrm{band}$ & HPTLC & [7] \\
\hline $0.1 \%$ ortho phosphoric acid: Methanol (20:80)/294 & $0.1-200$ & RP-HPLC & [8] \\
\hline Water: Acetonitrile $(60: 40) / 294$ & $2.4-5.6$ & RP-HPLC & [9] \\
\hline Phosphate buffer ( $\mathrm{pH} 4$ ): Acetonitrile (60:40)/299 & $5-100$ & $\begin{array}{c}\text { RP-UFLC } \\
\text { (Stability indicating) }\end{array}$ & {$[10]$} \\
\hline $\begin{array}{l}\text { Ammonium acetate buffer: ACN }(60: 40) / 294 \\
\text { Methyl paraben }(254 \mathrm{~nm}) \text { and } \\
\text { Related substances }(294 \mathrm{~nm})\end{array}$ & - & $\begin{array}{l}\text { RP-HPLC } \\
\text { Related substances } \\
\text { (Gradient mode) }\end{array}$ & [11] \\
\hline Methanol: Water $(80: 20) / 296$ & $2-14$ & Experimental design & {$[12]$} \\
\hline $\begin{array}{l}\text { Tetra butyl ammonium hydrogen sulphate: Acetoni- } \\
\text { trile (32: 68)/220 }\end{array}$ & $0.1-100$ & $\begin{array}{c}\text { RP-UFLC } \\
\text { (Stability indicating) } \\
\text { (Ion pairing reagent) }\end{array}$ & $\begin{array}{l}\text { Present } \\
\text { method }\end{array}$ \\
\hline
\end{tabular}

Table 1: Review of literature. 
Development and Validation of a New Stability Indicating Ultra-Fast Liquid Chromatographic (RP-UFLC) Method for the Quantification of Luliconazole

\begin{tabular}{|l|c|c|c|c|c|c|c|}
\hline Trial & Column & $\begin{array}{c}\text { Mobile } \\
\text { phase (v/v) }\end{array}$ & $\begin{array}{c}\text { Flow rate } \\
\text { (mL/min) }\end{array}$ & $\begin{array}{c}\text { Retention } \\
\text { time (min) }\end{array}$ & $\begin{array}{c}\text { Theoretical } \\
\text { plates }\end{array}$ & $\begin{array}{c}\text { Tailing } \\
\text { factor }\end{array}$ & Remarks \\
\hline 1 & $\begin{array}{c}\text { Phenomenex C18 } \\
\text { column }\end{array}$ & $20: 80$ & 0.8 & 2.175 & 1091.03 & 1.451 & $\begin{array}{c}\text { Theoretical plates } \\
<2000\end{array}$ \\
\hline 2 & $\begin{array}{c}\text { Phenomenex C18 } \\
\text { column }\end{array}$ & $25: 75$ & 0.8 & 2.548 & 3207.312 & 1.576 & Peak splitting \\
\hline 3 & $\begin{array}{c}\text { Phenomenex C18 } \\
\text { column }\end{array}$ & $25: 75$ & 0.6 & 3.426 & 3315.824 & 1.591 & Peak splitting \\
\hline 4 & $\begin{array}{c}\text { Phenomenex C18 } \\
\text { column }\end{array}$ & $30: 70$ & 0.8 & 2.680 & 3764.071 & 1.014 & Peak splitting \\
\hline 5 & Zorbox C8 column & $32: 68$ & 1.0 & 2.211 & 4504.437 & 1.256 & Method optimized \\
\hline
\end{tabular}

Table 2: Method optimization.
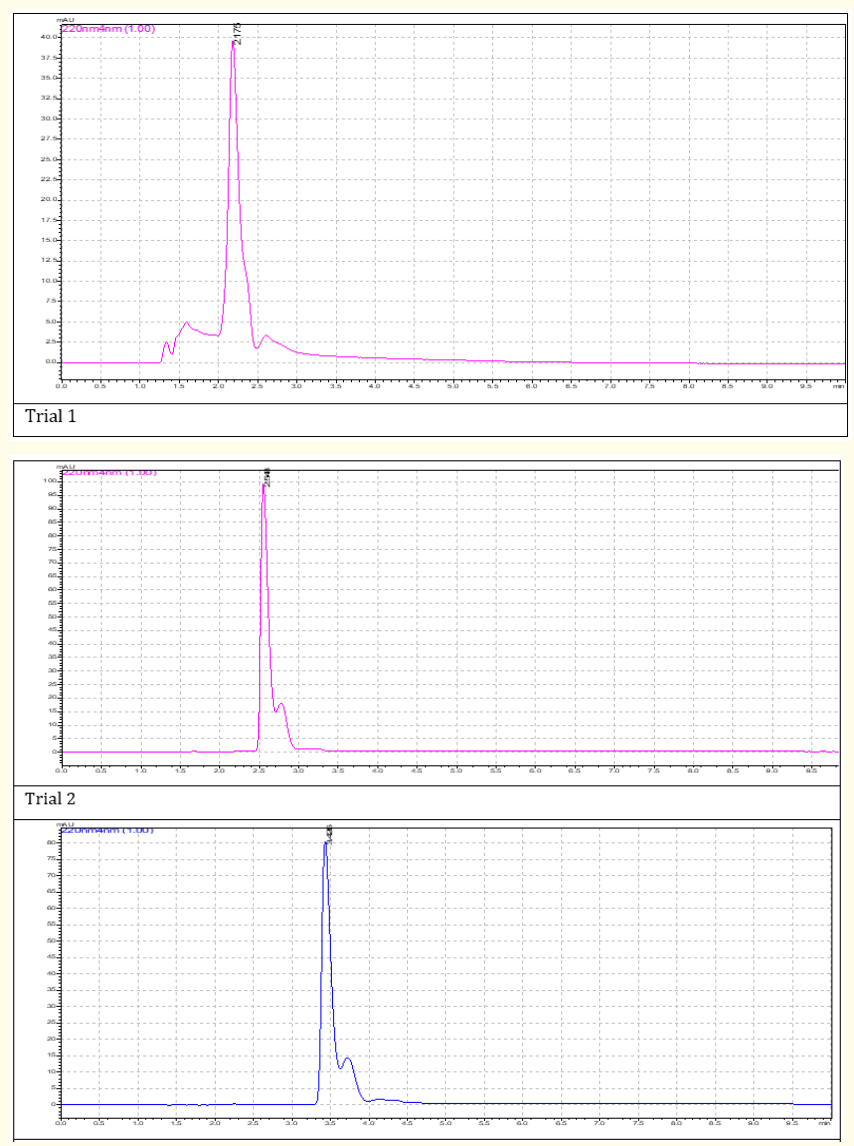
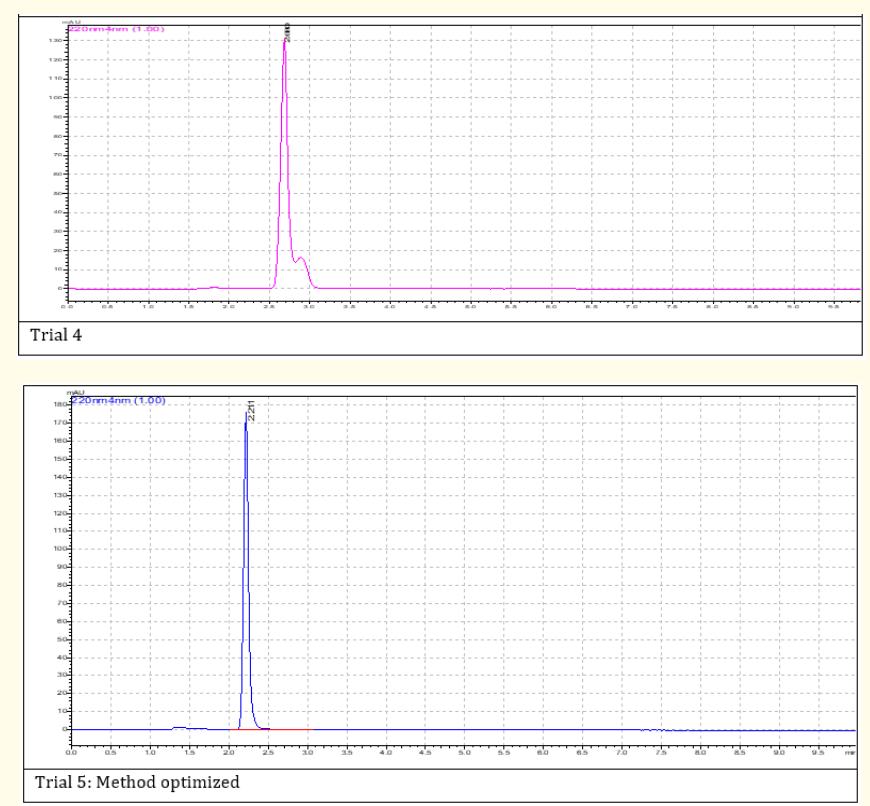

Figure 2: Chromatograms obtained during optimization.

\section{Method validation}

Luliconazole obeys Beer-Lambert's law over the concentration range of $0.1-100 \mu \mathrm{g} / \mathrm{mL}$ (Table 3 ) with linear regression equation $\mathrm{y}=89055 \mathrm{x}-1545.2\left(\mathrm{R}^{2}=0.9998\right)$ (Figure 3). The LOD and LOQ were found to be 0.0311 and 0.0981 respectively. The \% RSD was found to be 0.01-0.24 (Intraday) (Table 4) and 0.23-0.44 (Inter- 
Development and Validation of a New Stability Indicating Ultra-Fast Liquid Chromatographic (RP-UFLC) Method for the Quantification of Luliconazole

day) (Table 5) in precision studies which is less than 2.0 indicating that the method is precise. The \% recovery in accuracy studies was found to be 99.37-99.73\% (Table 6) and \% RSD was (0.35-0.62) less than $2 \%$ indicating that the method is accurate. The \% RSD in robustness study was found to be $0.23-1.21$ which was less than $2 \%$ indicating that the method is robust (Table 7 ). In all the validation studies the system suitability parameters were within the acceptable criteria.

\begin{tabular}{|l|c|c|}
\hline Conc. $(\boldsymbol{\mu g} / \mathbf{m L})$ & *Mean peak area & \% RSD \\
\hline 0.1 & 9019 & 0.28 \\
\hline 0.2 & 17859 & 0.26 \\
\hline 0.5 & 44234 & 0.34 \\
\hline 1 & 89596 & 0.61 \\
\hline 2 & 178957 & 0.24 \\
\hline 5 & 440856 & 0.39 \\
\hline 10 & 895496 & 0.41 \\
\hline 20 & 1786259 & 0.53 \\
\hline 40 & 3536985 & 0.81 \\
\hline 60 & 5396547 & 0.73 \\
\hline 80 & 6989654 & 0.89 \\
\hline 100 & 8985176 & 0.92 \\
\hline
\end{tabular}

Table 3: Linearity study of Luliconazole.

*Mean of three replicates.

\begin{tabular}{|l|c|c|}
\hline \multirow{2}{*}{ Conc. $(\boldsymbol{\mu g} / \mathbf{m L})$} & \multirow{2}{*}{ *Mean peak area } & Statistical Analysis \\
\cline { 2 - 2 } & & *Mean \pm SD (\% RSD) \\
\hline 10 & 895496 & \multirow{2}{*}{$894626 \pm 2178.44(0.24)$} \\
\hline 10 & 896235 & \\
\hline 10 & 892147 & \\
\hline 20 & 1786259 & \multirow{2}{*}{$1786117 \pm 166.33(0.01)$} \\
\hline 20 & 1786158 & \\
\hline 20 & 1785934 & \\
\hline 40 & 3536985 & \multirow{2}{*}{$3537268 \pm 544.75(0.02)$} \\
\hline 40 & 3537896 & \multirow{2}{*}{} \\
\hline 40 & 3536923 & \\
\hline
\end{tabular}

Table 4: Intraday precision study of Luliconazole.

*Mean of three replicates.

\begin{tabular}{|l|c|c|c|c|}
\hline \multirow{2}{*}{$\begin{array}{l}\text { Conc. } \\
(\boldsymbol{\mu g} / \mathbf{~ m L})\end{array}$} & \multicolumn{3}{|c|}{$*$ Mean peak area } & \multirow{2}{*}{$\begin{array}{c}\text { Mean } \pm \text { SD (\% } \\
\text { RSD) }\end{array}$} \\
\cline { 2 - 4 } 10 & Day 1 & Day 2 & Day 3 & $\begin{array}{c}896161.67 \pm \\
2061.17(0.23)\end{array}$ \\
\hline 20 & 1786259 & 1784692 & 1785634 & $\begin{array}{c}1785528.33 \pm \\
5535.14(0.31)\end{array}$ \\
\hline 40 & 3536985 & 3537983 & 3537264 & $\begin{array}{c}3537410.67 \pm \\
15564.61(0.44)\end{array}$ \\
\hline
\end{tabular}

Table 5: Inter day precision study of Luliconazole.

*Mean of three replicates.

\begin{tabular}{|c|c|c|c|c|}
\hline $\begin{array}{l}\text { Spiked } \\
\text { Conc. } \\
(\mu \mathrm{g} / \mathrm{mL})\end{array}$ & $\begin{array}{c}\text { Formula- } \\
\text { tion }(\mu \mathrm{g} / \\
\mathrm{mL})\end{array}$ & $\begin{array}{c}\text { Total } \\
\text { Conc. } \\
(\mu \mathrm{g} / \mathrm{mL})\end{array}$ & $\begin{array}{c}\text { *Conc. Obtained } \\
(\mu \mathrm{g} / \mathrm{mL}) \pm \mathrm{SD} \\
(\% \mathrm{RSD})\end{array}$ & $\begin{array}{l}\% \text { Re- } \\
\text { covery }\end{array}$ \\
\hline \multirow{3}{*}{$10(50 \%)$} & 20 & 30 & \multirow{3}{*}{$\begin{array}{c}29.81 \pm 0.1033 \\
(0.35)\end{array}$} & \multirow{3}{*}{99.37} \\
\hline & 20 & 30 & & \\
\hline & 20 & 30 & & \\
\hline \multirow{3}{*}{$20(100 \%)$} & 20 & 40 & \multirow{3}{*}{$\begin{array}{c}39.89 \pm 0.2473 \\
(0.62)\end{array}$} & \multirow{3}{*}{99.73} \\
\hline & 20 & 40 & & \\
\hline & 20 & 40 & & \\
\hline \multirow{3}{*}{$30(150 \%)$} & 20 & 50 & \multirow{3}{*}{$\begin{array}{c}49.74 \pm 0.2039 \\
(0.41)\end{array}$} & \multirow{3}{*}{99.48} \\
\hline & 20 & 50 & & \\
\hline & 20 & 50 & & \\
\hline
\end{tabular}

Table 6: Accuracy study of Luliconazole.

*Mean of three replicates.

\begin{tabular}{|c|c|c|}
\hline Parameter & $\begin{array}{l}\text { Condi- } \\
\text { tion }\end{array}$ & $\begin{array}{c}* \text { Mean peak area } \pm \\
\text { SD }(\% \text { RSD })\end{array}$ \\
\hline \multirow[t]{3}{*}{ Flow rate $( \pm 0.1 \mathrm{ml} / \mathrm{min})$} & 0.9 & \multirow{3}{*}{$\begin{array}{c}898962 \pm 10877.44 \\
(1.21)\end{array}$} \\
\hline & 1.0 & \\
\hline & 1.1 & \\
\hline \multirow{3}{*}{$\begin{array}{l}\text { Detection wavelength }( \pm \\
2 \mathrm{~nm})\end{array}$} & 222 & \multirow{3}{*}{$\begin{array}{c}896598 \pm 2062.18 \\
(0.23)\end{array}$} \\
\hline & 220 & \\
\hline & 218 & \\
\hline \multirow{3}{*}{$\begin{array}{l}\text { Mobile phase composition } \\
\text { Tetra butyl ammonium } \\
\text { hydrogen sulphate: Aceto- } \\
\text { nitrile }( \pm 2 \%, v / v)\end{array}$} & 30: 70 & \multirow{3}{*}{$\begin{array}{c}895341 \pm 0.0002 \\
(0.34)\end{array}$} \\
\hline & $32: 68$ & \\
\hline & $34: 66$ & \\
\hline
\end{tabular}

Table 7: Robustness study of Luliconazole $(10 \mu \mathrm{g} / \mathrm{mL})$.

*Mean of three replicates. 


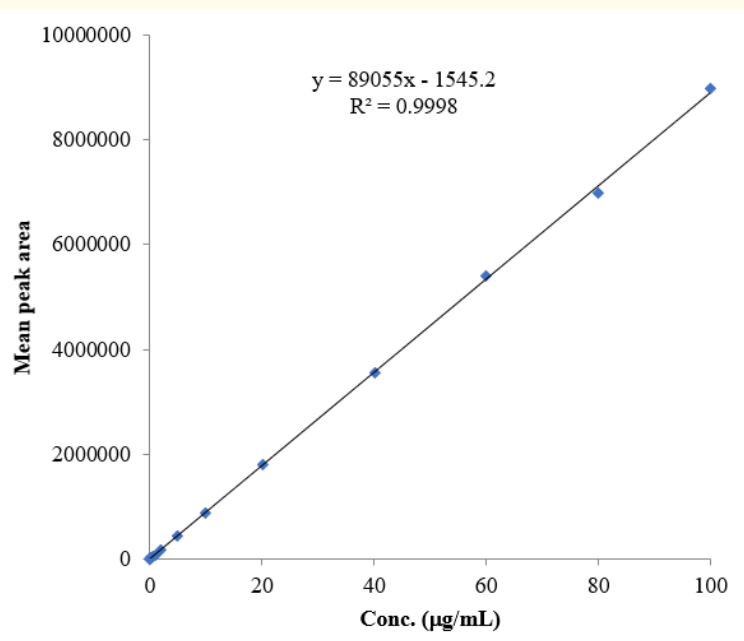

Figure 3: Calibration curve of Luliconazole.

\section{Forced degradation studies}

Luliconazole standard was eluted at 2.236 min with theoretical plates more than 2000 (4776.817) and tailing factor less than 1.5 (1.165) indicating that the system suitability parameters are within the acceptable criteria. During the forced degradation studies Luliconazole was observed to be more sensitive towards acidic degradation and oxidative degradation in comparison to alkaline degradation. In these degradations the more than $15 \%$ of Luliconazole has undergone degradation. During alkaline and oxidation degradation reactions extra peaks were observed at $1.616 \mathrm{~min}$ and 1.744 min respectively with resolution values 5.518 and 3.550 which is greater than 2 . The proposed method is specific as the degradants eluted were not interfering with Luliconazole peak. The $\%$ recovery during the degradation studies was with other system suitability parameters were shown in table 8. The corresponding chromatograms observed during the forced degradation studies were shown in figure 4.

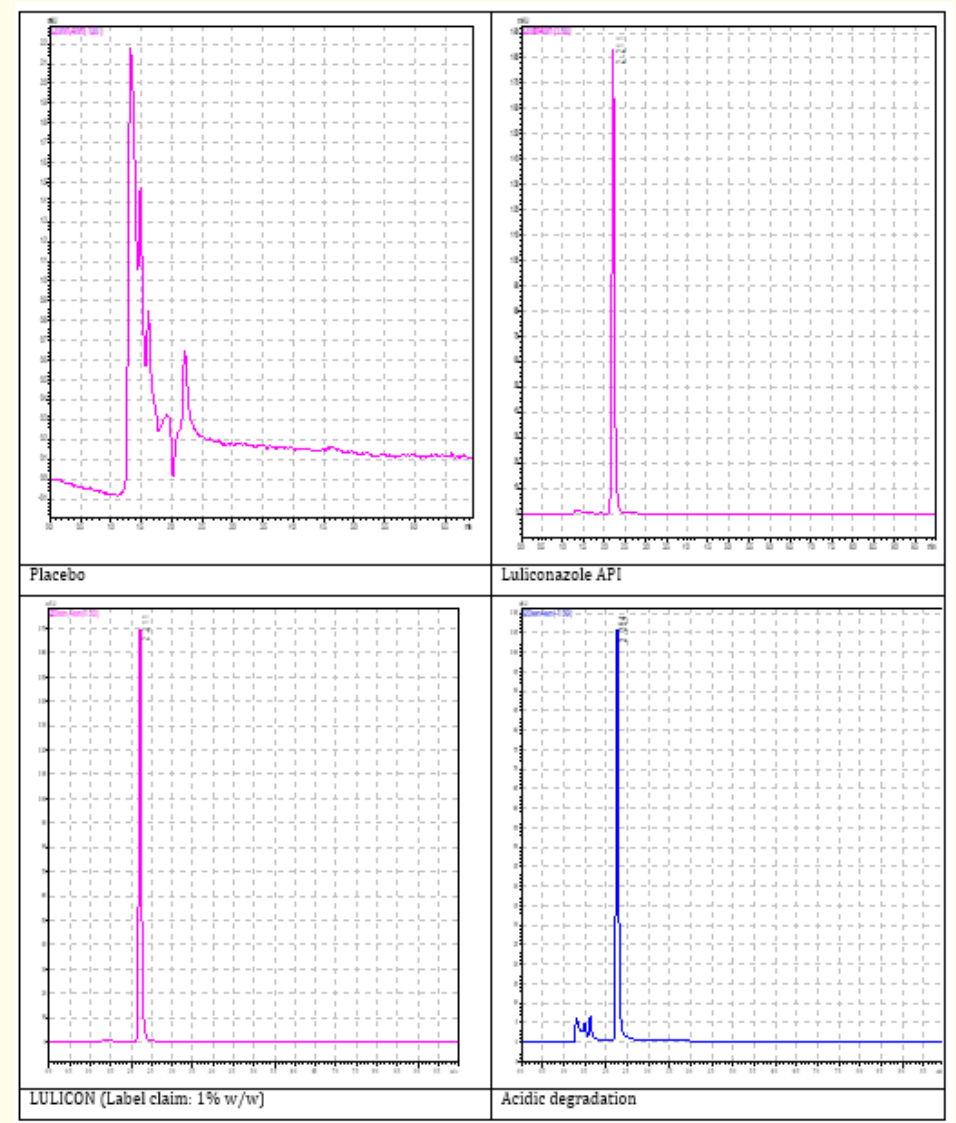

Citation: Paladugu Venkata Naveen and Seru Ganapaty. "Development and Validation of a New Stability Indicating Ultra-Fast Liquid Chromatographic (RP-UFLC) Method for the Quantification of Luliconazole". Acta Scientific Pharmaceutical Sciences 5.10 (2021): 21-28. 


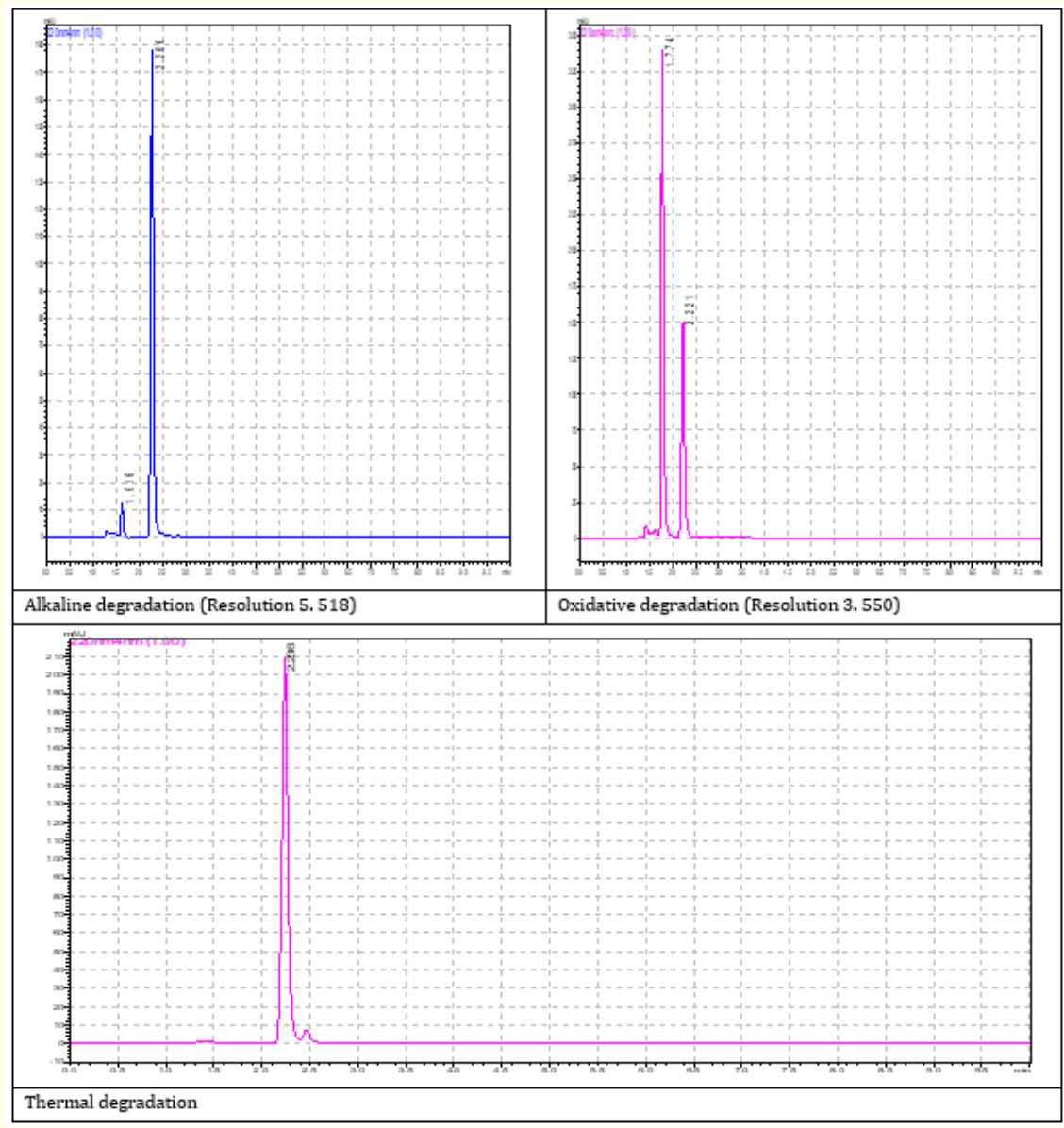

Figure 4: Representative chromatograms of Luliconazole $(10 \mu \mathrm{g} / \mathrm{mL})$ and its marketed products during degradation studies.

\begin{tabular}{|c|c|c|c|c|c|c|}
\hline Stress condition & Rt (min) & $\begin{array}{l}\text { Mean peak } \\
\text { area }\end{array}$ & $\begin{array}{c}\% \\
\text { Recovery }\end{array}$ & \% Drug degradation & $\begin{array}{c}\text { Theoretical } \\
\text { plates }(>2000)\end{array}$ & $\begin{array}{c}\text { Tailing } \\
\text { factor }(<1.5)\end{array}$ \\
\hline Standard drug & 2.236 & 895496 & 100 & - --- & 4776.817 & 1.165 \\
\hline $\begin{array}{l}\text { Acidic degradation } \\
0.1 \mathrm{~N} \mathrm{HCl} / 80^{\circ} / 1 \text { hour }\end{array}$ & 2.254 & 466229 & 52.06 & 47.94 & 5039.192 & 1.333 \\
\hline $\begin{array}{l}\text { Alkaline degradation } \\
0.1 \mathrm{~N} \mathrm{NaOH} / 80^{\circ} / 1 \text { hour }\end{array}$ & $\begin{array}{l}2.266 \\
1.616\end{array}$ & 754474 & 84.25 & 15.75 & 5632.688 & 1.227 \\
\hline $\begin{array}{l}\text { Oxidative degradation } \\
30 \% \mathrm{H}_{2} \mathrm{O}_{2} / 80^{\circ} / 1 \text { hour }\end{array}$ & $\begin{array}{l}2.221 \\
1.744 \\
\end{array}$ & 697398 & 77.88 & 22.12 & 4042.078 & 1.267 \\
\hline $\begin{array}{l}\text { Thermal degradation } \\
80^{\circ} / 1 \text { hour }\end{array}$ & 2.211 & 829463 & 92.63 & 7.37 & 4395.765 & 1.263 \\
\hline
\end{tabular}

Table 8: Forced degradation studies of Luliconazole.

*Mean of three replicates. 
Assay of Luliconazole in its topical dosage form (Cream)

The assay of Luliconazole was found to be 98.31-99.34 (Table 9) in creams. The individual chromatograms observed for the placebo and the Luliconazole cream formulation were shown in figure 4.

\begin{tabular}{|l|c|c|c|c|}
\hline S. No. & $\begin{array}{c}\text { Brand } \\
\text { name }\end{array}$ & $\begin{array}{c}\text { Label claim } \\
(\mathbf{\%} \mathbf{w} / \mathbf{w})\end{array}$ & $\begin{array}{c}\text { Observed } \\
\text { amount } \mathbf{\% w} / \mathbf{w})\end{array}$ & $\begin{array}{c}\text { \% Recov- } \\
\text { ery* }\end{array}$ \\
\hline 1 & Brand I & 1 & 0.9831 & 98.31 \\
\hline 2 & Brand II & 1 & 0.9934 & 99.34 \\
\hline
\end{tabular}

Table 9: Assay of Luliconazole cream.

\section{Conclusion}

The present proposed RP-UFLC method was validated and it is precise, accurate, robust and economical and used for the estimation of pharmaceutical formulations such as creams etc.

\section{Acknowledgement}

The authors are grateful to Glenmark Pharmaceuticals, India for providing the gift samples of Luliconazole. The authors have no conflict of interest.

\section{Bibliography}

1. Poojary SA. "A review and their role in current management of dermatophytoses". Clinical Dermatology Review 1.3 (2017): 24-29.

2. Deepashikha K and Subhash B. "Luliconazole for the treatment of fungal infection: an evidence based review". Core Evidence 9 (2014): 113-124.

3. Noopur JD and Dilip GM. "UV spectrophotometric method for the estimation of Luliconazole in marketed formulation". Pharma Science Monitor 5.2 (2014): 48-54.

4. Sowjanya G and Mohana K. "Quantification and stability aspects of Luliconazole in bulk and pharmaceutical dosage forms by UV spectroscopy". Journal of Drug Delivery and Therapeutics 9.2-s (2019): 300-306.

5. Chaudhari MJ., et al. "Application of area under curve technique for UV- Spectrophotometric determination of Luliconazole in bulk and pharmaceutical formulation". Asian Journal of Pharmaceutical Analysis 8.1 (2018): 45-48.

6. Sultan MA., et al. "Stability indicating method for the determination of Luliconazole by TLC and HPTLC - densitometry in bulk powder and cream dosage form". Journal of Planar Chromatography 30.1 (2017): 68-74.
7. Santosh RT., et al. "Estimation of Luliconazole in formulation and biofluid". Journal of Analytical and Pharmaceutical Research 6.5 (2017): 00187.

8. Gummadi S and Kommoju M. "Development and validation of a chromatographic assay method for the determination of Luliconazole in creams". International Journal of Pharmaceutical Sciences and Research 11.9 (2020): 4622-4628.

9. Tomal Majumder., et al. "Method development and validation of RP-HPLC method for estimation of Luliconazole in marketed formulation (Cream)". Pharma Innovation 8.5 (2019): 103-108.

10. Palyam Bhanu., et al. "A new stability indicating RP-UFLC method for determination of Luliconazole in bulk and pharmaceutical formulation". Research Journal of Pharmacy and Technology 13.6 (2020): 2859-2863.

11. Aditi M and Anju G. "Method development and validation of RP HPLC method for assay and related substances of Luliconazole in topical dosage form". International Journal of Pharmaceutical Chemistry and Analysis 4.2 (2017): 46-50.

12. Sandeep S and Paraag G. "Application of experimental design for the optimization of forced degradation and development of a validated stability-indicating LC method for Luliconazole in bulk and cream formulation". Arabian Journal of Chemistry 9.2 (2016): 1428-1434.

13. ICH Validation of analytical procedures: Text and methodology Q2 (R1), International Conference on Harmonization (2005).

14. ICH Stability testing of new drug substances and products Q1A (R2), International Conference on Harmonization (2003).

\section{Volume 5 Issue 10 October 2021 \\ (C) All rights are reserved by Paladugu Venkata Naveen and Seru Ganapaty.}

